\title{
Online Exam Vigilantes at Australian Universities: Student Academic Fraudulence and the Role of Universities to Counteract
}

\author{
Sabina Cerimagic ${ }^{1, *}$, M. Rabiul Hasan ${ }^{2}$ \\ ${ }^{1}$ Faculty of Medicine and Health, University of Sydney, Australia \\ ${ }^{2}$ School of Computer Science, University of Sydney, Australia
}

Copyright $\bigcirc 2019$ by authors, all rights reserved. Authors agree that this article remains permanently open access under the terms of the Creative Commons Attribution License 4.0 International License

\begin{abstract}
In this research pilot, the authors are taking an elemental look at exam vigilantes and in a broader sense academic fraudulence. In the last decade, there has been an increasing number of universities offering online degrees. Along with this new method of completing degrees comes a new body of academic dishonesty and misconduct. Not only is academic dishonesty widespread, it is also often underestimated by universities. Additionally, today's technological advances have enabled students to cheat in several different ways. Nonetheless, technology can also be used to combat the issue of cheating by employing biometrics to identify students based on physiological and behavioural characteristics and by applying the use IP addresses as a tool to identify collusions. Although most of the research on this topic has focused on the United States (US), this paper the will exclusively focus on how it applies to the Australian university landscape.
\end{abstract}

Keywords Online Degrees, Online Exams, Exam Vigilantes, Biometric Systems, Academic Dishonesty and Misconduct

\section{Introduction}

The ever-increasing body of research on academic dishonesty and misconduct reflects widespread concern about these practices (Kerkvliet, 1994; de Lambert, Ellen and Taylor, 2003; Brimble and Stevenson-Clarke, 2006; Teixeira and Rocha, 2010). Glater (2006) warns of the alarming magnitude of cheating among university students, the increasing pervasiveness of the phenomenon within academia, and the detrimental impact it might have on the 'real world,' as the decisions students make once they leave university and commence working are influenced by their perception of ethical behaviour (Lawson, 2004; Teixeira and Rocha, 2006). Brimble and Stevenson-Clarke (2006) find that not only is academic dishonesty widespread, it is also often underestimated by universities.

According to Rokavski and Levy (2007), cheating at universities is growing at a rampant rate. Researchers found academic dishonesty and misconduct at universities during the turn on the millennia was more prevalent than before due to technological advances, relatively scarce resources and understaffing at universities (Treviño and Butterflied, 1999; Maslen, 2003; Etter et al., 2006; Devlin and Gray, 2007; Howard and Davies, 2009). The most common and widely used notion of academic dishonesty and misconduct at universities is copying and/or cheating on an exam (Teixeira and Rocha, 2010), hence, this paper examines academic dishonesty in relation to online exams.

These global findings also apply to Australian universities. Brimble and Stevenson-Clarke (2006) conducted one of the largest studies on this topic that focuses on Australian students. In their research, they surveyed 1,206 students and 190 academic staff across four Queensland universities. They found academic dishonesty and misconduct is widespread and universities are not doing enough to limit it.

The corruption watchdog (Australia) said in order to deal with academic dishonesty and misconduct, universities must separate their compliance functions from their business development functions and limit the number of overseas agents they deal with. They argued that when these functions are combined, there is less incentive for universities to address academic dishonesty. The paper said:

The gap between student capabilities and academic demands increases the likelihood that students will offer inducements to academics in order to pass courses and conversely, makes students more vulnerable to improper demands from academics . . . With universities in NSW financially dependent on the success of international 
students, academics may be encouraged to admit students they would otherwise reject, to turn a blind eye to cheating and to mark the work of poor-performing students favourably to enable them to pass. (Independent Commission Against Corruption (I.C.A.C), NSW, 2015).

There have been documented examples of academic dishonesty at Australian universities. According to extensive research into cheating in online degrees at Australian universities by Smith and Clarke (2017), universities are not vigilant enough. The research found 97 per cent of universities did not check if exam invigilators had a conflict of interest between themselves and the student they supervised.

Additionally, in their paper Smith et al., (2017), state 35 per cent of the exam invigilators were related (known and connected in a form of relation) to the student they supervised; a further 44 per cent were friends with the students they supervised and six per cent were dating. Yet they were all approved to work as exam invigilators that supervise online exams.

In their findings Smith et al., (2017), also highlighted 72 per cent of study participants knew firsthand of students who had cheated while completing an online degree. They go on to say:

According to Bushway and Nash (1977, p. 624) a "majority of studies indicated that students who are lower in school achievements may cheat more frequently." According to researchers such as Hrabak et al. (2004) and Bisping et al. (2008), attitudes to cheating could be linked to a low-grade point average (G.P.A). The G.P.A is a numerical calculation, weighted by credit points, of the mean of the grades received by a student over a defined study period (e.g. a semester) or over an entire program (Federation University Australia). Research shows that students with a higher G.P.A. are less likely to cheat as they have less to gain and more to lose if they caught when compared to students who have a lower G.P.A. (Nowell and Laufer, 1997). This is supported by the research of Kerkvliet (1994) and Kerkvliet and Sigmun (1999), which indicate that cheating is related to the perceived costs and benefits of cheating.

More recently, researchers have found technology has enabled students to cheat in several different ways (Etter et al., 2006; Howard and Davies, 2009; Simkin and McLeod, 2010). The author noticed some current online programs at Australian universities send invigilators hardcopy exams, which are supervised by invigilators whose identities are not verified. For example, technology makes it much easier for students to collusion on exams that are meant to be an individual effort.

The widespread concern about academic dishonesty and misconduct is reflected in the ever-increasing body of research on these practices (Kerkvliet, 1994; de Lambert, Ellen and Taylor, 2003; Brimble and Stevenson-Clarke,
2006; Teixeira and Rocha, 2010; Wilkinson, 2009; Allen et al. 2013; Stack, 2015). Glater (2006) warns of the alarming magnitude of cheating among university students, the increasing pervasiveness of the phenomenon within academia and the detrimental impact it might have on the 'real world,' as the decisions students make once they leave university and commence working are influenced by their perception of what comprises ethical behaviour (Lawson, 2004; Teixeira and Rocha, 2006).

Research conducted by Brown, Weible and Olmosk (2010) found that 49 per cent of students in undergraduate marketing classes admitted to cheating in 1988 versus 100 per cent of the students in an undergraduate management class in 2008.

This paper uses the general definition of cheating from Sheard et al. (2003, p. 92), who defines cheating as " $a$ series of practices, which cover a range of areas that can be defined as illegal, unethical, immoral or against the regulations of the course or institution." This definition identifies the long-term problems that occur when students engage in academic dishonesty. If cheating is illegal, unethical and/or immoral, what will stop a student who engages in this type of behaviour (for example, cheating on their exams or falsifying a term project) from falsifying records or cheating on an expense account when they enter the workforce?

Australian universities are not an exception to this phenomenon. Brimble and Stevenson-Clarke (2006) conducted one of the largest studies on this topic that focuses on Australian students. In their research, they surveyed 1,206 students and 190 academic staff across four Queensland universities. They found academic dishonesty and misconduct is widespread and that universities are not doing enough to limit it. This was confirmed by Wilkinson (2009) and Eriksson and McGee (2015), who conducted research on cheating at Australian universities. These researchers found more proactive strategies need to be implemented by universities to prevent student involvement in academic dishonesty.

According to research conducted by Lawson (2004), there is a strong relationship between a student's predisposition to engage in unethical behaviour, such as cheating in an academic setting, and their attitude towards such behaviours in the business world. Furthermore, research suggests that students, who engage in dishonest behaviour, for example cheating on exams, are less likely to believe people in the business world act ethically. They are also more accepting of unethical behaviours in business than those who did not engage in academic dishonesty (Lawson, 2004; Brimble and Stevenson-Clarke, 2006). Given the ongoing implications of academic dishonesty, it is important this subject be further investigated.

\section{Methodology}

This research began with an examination of the existing 
literature on academic dishonesty and misconduct in online programs and online exams. The literature review was followed by a survey, which had four closed ended questions with "yes" and "no" options, five-point Likert scale questions, and two open ended questions.

The survey participants were exam invigilators who supervised students doing online degrees in Australia between 2010 and 2018. In this research, 68 exam invigilators were contacted via email and invited to participate in the study. Sixty-three per cent of the target participants (43 exam invigilators) completed and returned the survey in approximately two weeks.

This survey was developed using the online survey tool, 'Survey Monkey'. This software helped with the collection of the survey and it assisted with the analyses of the results.

This is a pilot study. Once the results of the pilot study are analysed, a larger study, which contain will inculcate interviews, will be conducted.

\section{Results}

The participants of this study report that they have firsthand knowledge of 81 per cent of the students cheating or attempted to cheat in an online exam.

Although the findings concerning the possibility and amount of cheating in online courses is concerning, there are several measures universities can take to minimise cheating. Penalties and minimising opportunities for students to engage in academic dishonesty and misconduct can be highly effective (Haswell, Jubb and Wearing, 1999).

Ninety-one per cent of exam invigilators in this survey believe cheating is so prominent as the penalties for students who cheat are not tough enough. Additionally, on alarming 96 per cent of the exam invigilators in this study did not see any reason to report a student cheating as there were no 'real' consequences for the student and it was expected of the exam invigilators to 'prove' that the student was cheating.

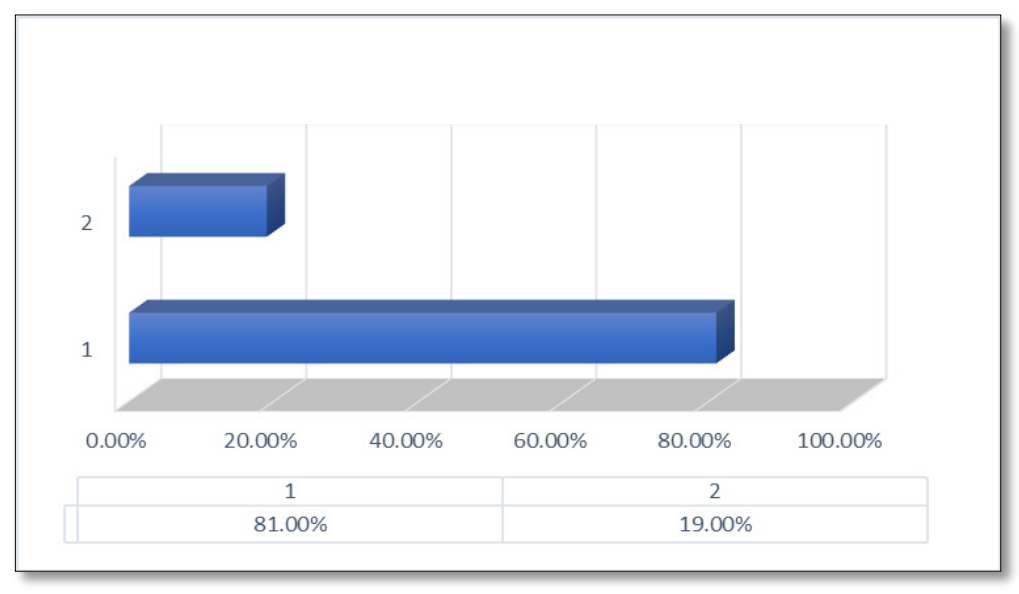

Figure 1. Firsthand knowledge of students cheating or attempted to cheat in an online exam

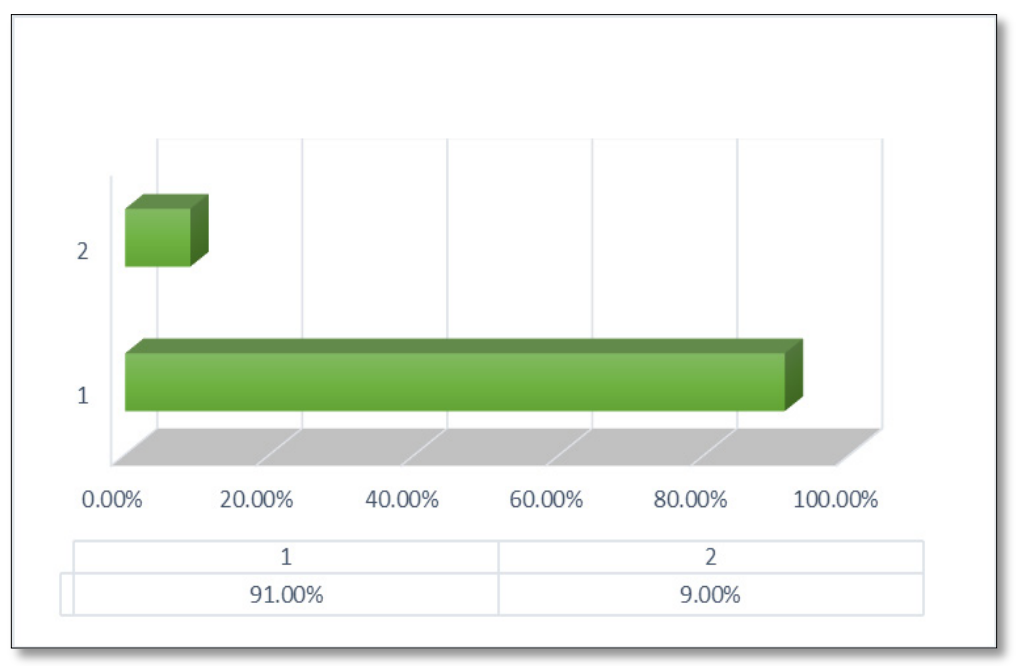

Figure 2. Penalties for students who cheat are not tough enough 


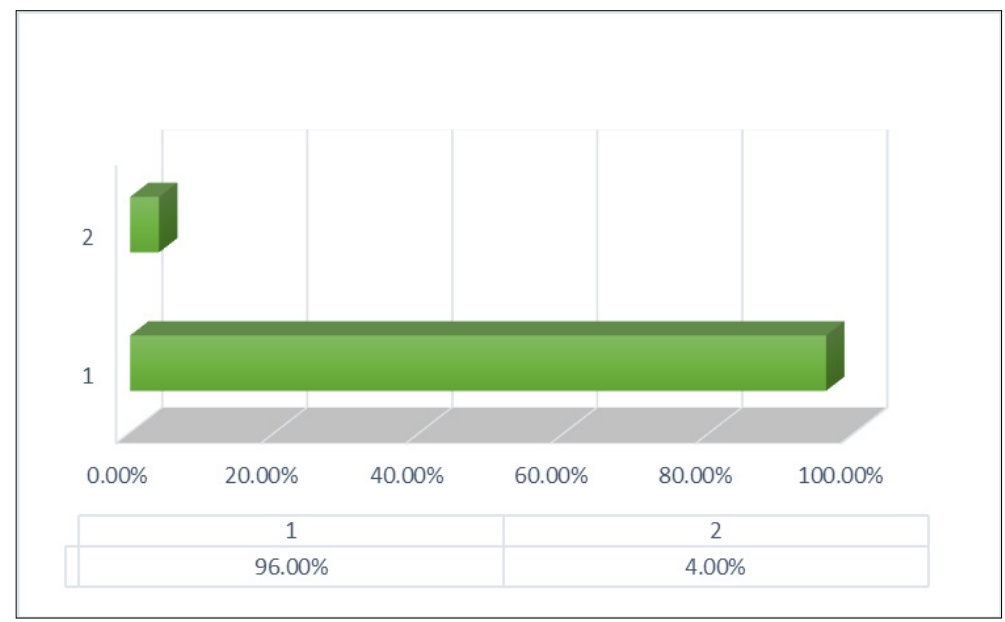

Figure 3. Exam invigilators not reporting cheating students

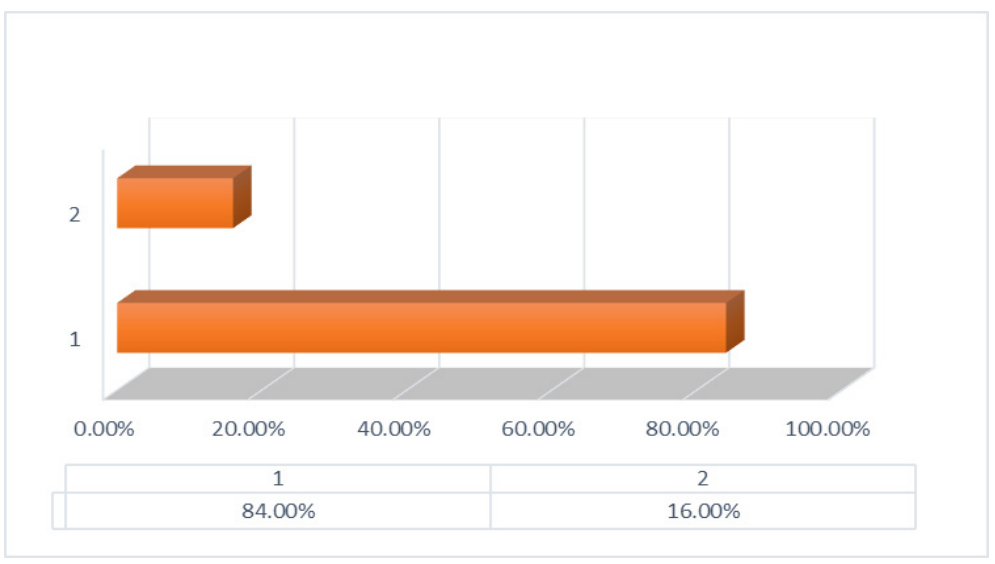

Figure 4. Cheating students' likelihood to cheat in other areas of their life and work

This result is supported by earlier research conducted by Haswell, Jubb and Wearing (1999) which studied students from universities in Australia, the United Kingdom and South Africa. The report examined how the willingness of students to engage in a variety of forms of plagiarism in a risk-free environment decreased dramatically when the detection risk increased, and substantial penalties were introduced. They found the size of the penalty must exert a greater influence than the risk of detection in order to be an effective deterrent. According to Woessner (2004), universities failing to apply heavy penalties can be tantamount to encouraging academic dishonesty and misconduct, as it presents an excellent gamble to students. Those findings, in conjunction with evidence academic misconduct is highly prevalent in Australian universities, presents a worrying picture of student behaviour and the performance of universities in terms of teaching, learning and producing ethical employees.

The study participants also state ( 84 per cent) they believe students who cheat on assessments are less knowable and are more likely to cheat in other areas of their life and work. Academic dishonesty and misconduct have serious and negative consequences for the quality of learning in Australian universities and will have flow-on effects in industries and societies at large. If there are no major changes to University policies to ensure universities enforce strict penalties and minimise opportunities for students to engage in academic dishonesty and misconduct, the current situation will prevail.

Research in the area of online degrees have indicated most online degrees will give examinations with little or no supervision, compared to traditional classes where examination is supervised (Stack, 2015). There is also evidence that cheating on online degrees is up to four times higher than cheating in a traditional class setting (Moten, et al., 2013). Furthermore, data in this area indicates higher self-reported instances of cheating in online classes compared to traditional class settings (Lanier, 2006; Moten, et al., 2013). According to researchers such as Means, Toyama, Murphy et al., (2010), students perform better in an online setting, which may indicate some students are cheating.

Following this pilot studies results; a detail literature review was done on how potentially students are cheating in a short-time framed supervised online exam at a Group of Eight (Go8) university in Australia. 
The flowchart in Figure 5 is the result of an hour scenario in the exam venue where many students participated in an online exam. After receiving the exam questions, students open and check questions. If they are confident to answer, they start answering the questions and complete the exam.

The following flowchart shows how students cheat in a short-time framed supervised online exam at a Group of Eight (Go8) university in Australia:

However, if they are not confident answering the question, they then copy the question and paste it into the Google Translate application. The translated texts are then copied and pasted into a local online support forum student are already familiar and experienced with. After posting their questions, they look for classmates or other support members in the forum. If they find peers or members with similar interests, they start a discussion and decide on answer. The students then start answering the questions and complete the exam. If they do not find anyone to support in the forum, they either leave the questions unanswered or they try to answer themselves and end with the exam.

Additionally, the invigilator may not be from the same cultural background and may not have language barriers that could be used to the benefit of the student's deceit. It is to be noted the translated texts copied from the Google Translate application and the discussion threads in the local online forum may not be understood by many of the invigilators who are not native to the students. Thus, students may take advantage by informally and non-verbally convincing the invigilators with some acts such as body-language that they are not doing anything wrong.

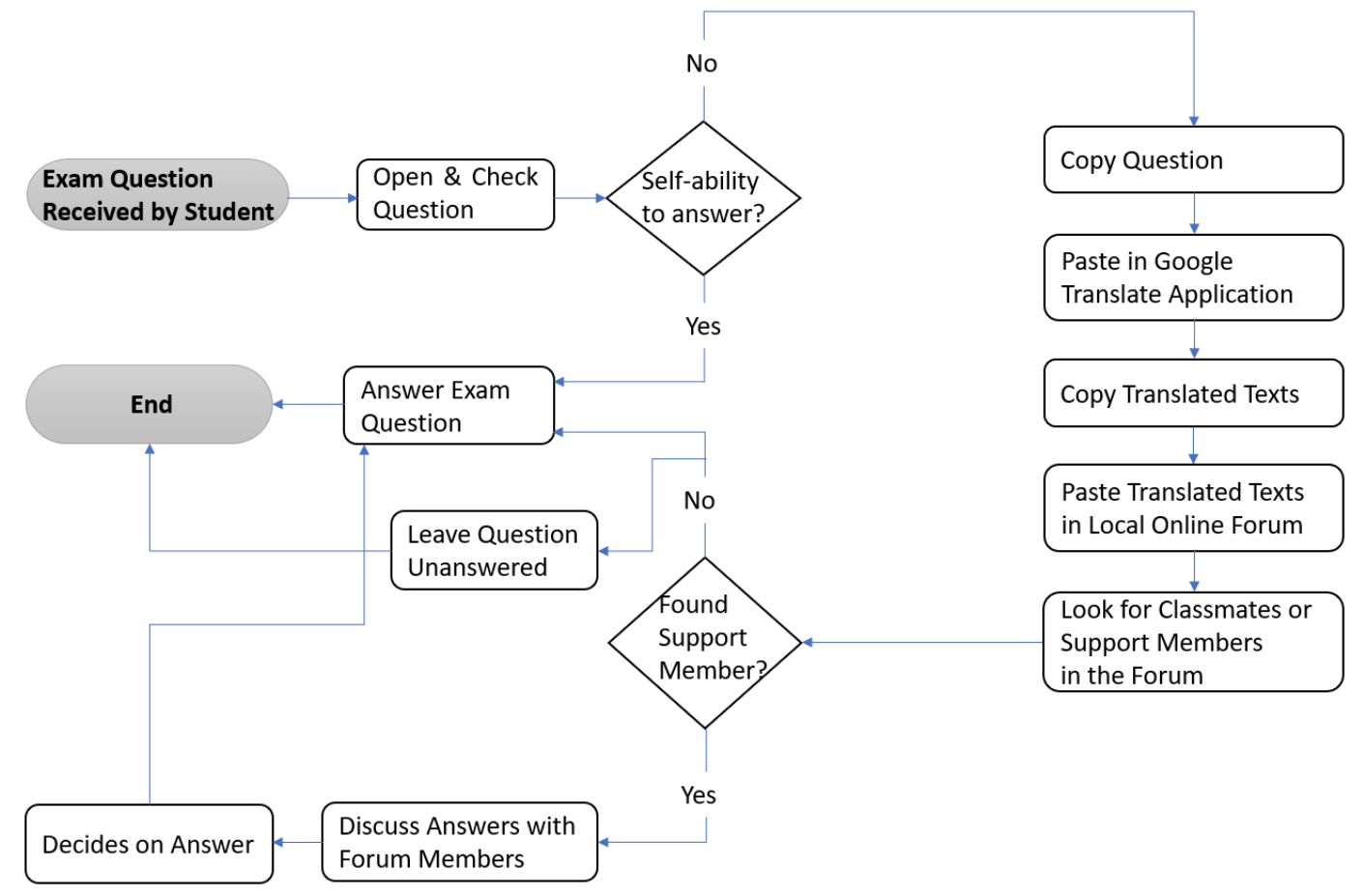

Figure 5. Student's decision-making in cheating in online exam

\section{Discussions and Recommendations}

There has been little research in Australia in the field of online degrees and cheating in online exams. Online education has thrived in the last decade, with a growing number of students taking online classes and degrees. With this increase comes an increase in academic dishonesty (Allen and Seaman, 2013; Stack, 2015).

Some research suggests than cheating can be addressed by using biometrics to identify students based on physiological and behavioural characteristics (Rabuzin, Baca and Sajko, 2006; Asha and Chellappan, 2008; Gao, 2012; Smith, et al. 2017). Biometrics commonly uses soft traits like gender, age, height, weight and ethnicity, physiological characteristics such as face, eye and hands and behavioural characteristics such as keystrokes, signature, mouse movement, voice, gait and pulse to recognise individuals. Two or more of the listed biometrics can be combined to improve the recognition accurateness.

The way this would work: first the student needs to register to a biometric system, where biometric data would be stored. The student then needs to provide the same biometric that was provided during registration to login to the system. Once the biometric data is entered, they will be processed with the same algorithm as those at registration and compared to the stored template. Some of the biometric systems currently used in universities are shown in Table 1.

Researchers in this area have proposed different biometric traits should be combined and used in the field of online learning. However, for biometrics to be effective, 
universities must give exams online rather than on paper. This is a logical extension to online studies; if students are doing an online degree, then their exams should be online too. Another tool that can be used with online exams is identified by Gao (2012), who suggests using IP addresses as tools to identify collusions.

If universities choose to post hard copies of exams to exam invigilators so students can do the exam off site, then universities need to do a background check on the exam invigilators. Universities have the reputation of moving at glacial pace, which means any change may take some time to be introduced. However, if more universities increasingly offer online degrees and courses, then universities need to ensure they do due diligence. Universities also need to look at the size of the penalty for academic dishonesty and ensure that it exerts a greater influence than the risk of detection. Research shows that students' willingness to engage in a variety of forms of plagiarism in a risk-free environment decreases dramatically when detection risk and substantial penalties are introduced.

There are numerous ways of dealing with the problem of academic dishonesty and misconduct. Based on the literature review (Hrabak et al. 2004; Rokavski et al. 2007; Bisping et al. 2008; Smith, 2017) and survey findings of this pilot study, suggestions are made in table 2 on how to deal with online exam vigilantes at Australian Universities and students' academic dishonesty and misconduct in general.

Table 1. Biometric systems currently used in universities

\begin{tabular}{|c|c|c|c|}
\hline Attribute & Securexam Student (SES) & Webassessor TM & ProctorU \\
\hline Description & $\begin{array}{l}\text { Securexam Remote Proctor is a small } \\
\text { device with a fingerprint scanner, } \\
\text { microphone and video camera with a } \\
\text { 360-degree view. To start an exam, } \\
\text { students need to provide their } \\
\text { fingerprints for identification. During } \\
\text { the exam, the microphone and video } \\
\text { look out for anything suspicious like an } \\
\text { unknown voice or movement on the } \\
\text { camera. }\end{array}$ & $\begin{array}{l}\text { Kryterion's Webassessor uses face } \\
\text { images captured by webcams and } \\
\text { uses keystroke biometrics (typing } \\
\text { styles) captured by software to } \\
\text { authenticate the test taker. It will } \\
\text { alert the proctors if it detects a new } \\
\text { user taking over. }\end{array}$ & $\begin{array}{l}\text { The system gathers personal data from a } \\
\text { variety of databases, including criminal } \\
\text { files and property records, and uses the } \\
\text { data to ask students a few questions, such } \\
\text { as address, employers, etc. Students need } \\
\text { to answer the questions correctly before } \\
\text { they can begin exams. In order to use } \\
\text { ProctorU, each student also needs to } \\
\text { reserve a time slot for an exam and have a } \\
\text { webcam ready that can monitor the exam } \\
\text { environment. Using a webcam, a human } \\
\text { proctor would remotely guide a student } \\
\text { in the process of starting an exam. }\end{array}$ \\
\hline College & Troy University, New York University & Penn State University & Swinburne Online \\
\hline Cost & $\$ 25.00$ USD per student annually & $\$ 50 \sim \$ 80$ USD per student & \$175 USD per student annually \\
\hline Company & Software Secure Inc. & Kryterion Inc. & Axicom Corp. \\
\hline Web & www.softwaresecure.com & www.kryteriononline.com & www.proctoru.com \\
\hline
\end{tabular}

Adapted from Qinghai Gao, 2012

Table 2. Recommendations

\begin{tabular}{l|l}
\hline Pilot study participants' feedback & Suggestions \\
\hline & $\begin{array}{l}\text { Try to minimise the problem from the get-go by not enrolling students with a low } \\
\text { G.P.A. (in Australia, often represented as a tertiary entrance ranking), as research } \\
\text { suggests a student's attitude to cheating could be linked to a low G.P.A. Research } \\
\text { shows students with a higher G.P.A. are less likely to cheat, as they have less to } \\
\text { gain and more to lose if they are caught in comparison to students with a lower } \\
\text { Eighty-one per cent of participants in this study } \\
\text { reported they have firsthand knowledge of students } \\
\text { cheating or attempting to cheat in an online exam. }\end{array}$ \\
$\begin{array}{l}\text { Gurther recommendations include the use IP addresses as tools to identify } \\
\text { collusions. }\end{array}$ \\
\hline
\end{tabular}

Ninety-one per cent of the exam invigilators in this survey believe cheating is prominent, due to the fact that penalties for students who cheat are not severe enough.

Ninety-six per cent of the exam invigilators in this pilot study did not see any reason to report a student cheating as there were no 'real' consequences for the student and it was expected of the exam invigilators to 'prove' the student was cheating.

Eighty-four per cent of study participants' state they believe students who cheat on assessments are less knowledgeable and are more likely to cheat in other Implement tougher and tough penalties for students who cheat. In addition, employ the use of biometrics to identify students.

Offer take-home exams to invigilators to reduce pressure. In case universities insist/prefer to use a paper exam, then they should supply and pay an exam invigilator. It is recommended students not be charged with finding and performing background checks on their exam invigilator.

Strengthening the teaching of ethics in program curricula. 
All the issues realised in this pilot could be potentially minimised, if not be eliminated, if biometrics are used to identify students and IP addresses used to identify collusions.

Those included in this pilot are only a few suggestions, and the authors recommend an in-depth case analysis with a large sample size be conducted to identify what may and may not work when it comes to the fight against academic dishonesty and misconduct.

\section{Conclusions}

Academic dishonesty and misconduct are enduring problem for tertiary institutions worldwide and one that directly impacts on the performance attributes of universities. A growing pool of research shows evidence that dishonest behaviour by students around the globe is predominant and ever increasing. The literature presents a worrying picture of student behaviour and in turn of the performance of Australian universities in term of teaching, learning and the worth of the degrees completed by students and scholarship.

As universities around Australia and the world are offering an increasing number of courses and degrees online, it is important to plan how to deal with the problem of academic dishonesty and misconduct; by for example introducing tougher consequences for students who engage in those activities. This research took into consideration only one type of cheating. Other sorts of academic dishonesty, for example plagiarism or employing assignment-writing companies, are beyond the scope of this paper. With many courses using an end-of-subject exam for up to $60 \%$ of the student's overall mark for the subject, it is vitally important cheating in exams be addressed. This research has found academic dishonesty and misconduct can be effectively addressed by using biometrics to identify students based on physiological and behavioural characteristics as well as IP addresses as tools to identify collusions.

\section{REFERENCES}

[1] Allen, I. E., and Seaman, J. (2013), Changing course: Ten years of tracking online education in the United States, Babson Survey Research Group, Pearson Publishers and Sloan Foundation.

[2] Asha, S., Chellappan, C., (2008), "Authentication of e-learners using multimodal biometric technology" International Symposium on Biometrics and Security Technologies, ISBAST. Islamabad.

[3] Berelson, B. (1952) Content analysis in communication research, Glencoe, Ill.: Free Press.

[4] Brimble, M. and Stevenson-Clarke, (2006), Managing academic dishonesty in Australian universities: Implications for teaching, learning and scholarship, Accounting, Accountability and Performance, 12 (1), 32-63.

[5] Brimble, M., and Stevenson-Clarke, P., (2006), Managing Academic Dishonesty in Australian Universities: Implications for Teaching, Learning and Scholarship, Accounting, Accountability \& Performance, 12(1), 32-63.

[6] Brown, B. S., Weible, R. J., \& Olmosk, K. E. (2010). Business school deans on student academic dishonesty: A survey. College Student Journal, 44, 299-309.

[7] Cerimagic, S. (2016) "Online degrees - academic dishonesty and misconduct, why is happening?" International Journal of Research and Development Organization, Volume 2, Issue: 3 .

[8] de Lambert, K., Ellen, N. and L. Taylor, (2003), Prevalence of Academic Dishonesty in Tertiary Institutions: The New Zealand Story, Working Paper, Christchurch College of Education.

[9] Devlin, Marcia; Gray, Kathleen, (2007). Higher Education Research and Development, Volume 26, Issue 2, pages 181-198.

[10] Eriksson L and McGee, T.R., (2015), Academic dishonesty amongst Australian criminal justice and policing university students: individual and contextual factors, International Journal for Educational Integrity 1-15.

[11] Etter, S., J. Cramer and Finn, S., (2006), Origins of Academic Dishonesty: Ethical Orientations and Personality Factors Associated with Attitudes About Cheating with Information Technology, Journal of Research on Technology in Education 39(2), 133-155.

[12] Federation University Australia, last accessed $14^{\text {th }}$ of December 2018. Link: https://federation.edu.au/.

[13] Gao, Q., (2012). "Biometric authentication to prevent cheating," International Journal of Instructional Technology and Distance Learning, vol. 9. no. 2, pp. 3-13, February 2012.

[14] Glater, J. (2006), Colleges chase as cheats shift to higher tech, The New York Times (May 18), A1-A24.

[15] Haswell, S., Jubb, P., and Wearing, B. (1999), Accounting students and cheating: A comparative study for Australia, South Africa, and the U.K., Teaching Business Ethics, 3, 211-239.

[16] Howard, R. M., \& Davies, L. J. (2009). Plagiarism in the Internet age. Educational Leadership, 66(6), 64-67.

[17] Kerkvliet, J. (1994), Cheating by economics students: A comparison of survey results. Journal of Economic Education, 25(2), 121-133.

[18] Kerkvliet, J., and Sigmun, C. L. (1999), Can we control cheating in the classroom? Journal of Economic Education, 30(4), 331-351.

[19] Lanier, M.M. (2006), Academic integrity in distance education, Journal of Criminal Justice Education, 17, 244-261.

[20] Lawson, R. (2004), Is Classroom Cheating Related to Business Students, Propensity to Cheat in the Real World?, 
Journal of Business Ethics 49(2), 189-199.

[21] Maslen, G. (2003), Dirty marks, The Bulletin pp. 18-22. June 10.

[22] Moten, J. Jr., Fitterer, A., Brazier, E., Leonard, J. and Brown, A. (2013), Examining online college cyber cheating methods and prevention measures, The Electronic Journal of e-Learning, 11, 139-146.

[23] Rokovski, C. and Levy, E. (2007), Academic Dishonesty: Perceptions of Business Students, College Student Journal 41(2), 466-481.

[24] Rabuzin, K., Baca, M., Sajko, M. (2006). "E-learning: Biometrics as a Security Factor" International Multi-Conference on Computing in the Global Information Technology, 2006. ICCGI. Bucharest.

[25] Sheard, J. and Dick, M. (2003), Influences on Cheating Practice of Graduate Students in IT Courses: what are the factors?, ACM SIGCSE Bulletin, 35(3), pp. 45-49.

[26] Sheard, J., Dick, M., Markham, S., Macdonald, I. and Walsh, M. (2002), Cheating and Plagiarism: Perceptions and Practices of First Year IT Students, Working Paper, Monash University.

[27] Smith, E., and Clarke, L., (2017) "Academic dishonesty and misconduct in online programs and online exams - an Australian study". International Journal of Research and Development Organization, Volume 3 Issue 2, February 2017.

[28] Smith, E.; Clarke, L. and Carmona, P., (2017) "Cheating in online exams at Australian universities". International Journal of Research and Development Organization, Volume 3 Issue 2, February 2017.

[29] Smith, E.; Clarke, L.; Carmona, P., and Cerimagic, S. (2017) "Academic fraudulence in online degrees and exams at Australian universities". International Journal of Research and Development Organization, Volume 3 Issue 2, February 2017.

[30] Stack, S. (2015), Learning Outcomes in an online vs traditional course, International Journal for the Scholarship of Teaching and Learning: Vol. 9: No. 1, Article 5.

[31] Teixeira, A. A. C., and Rocha, M. F. (2006), College cheating in Austria, Portugal, Romania and Spain: A comparative analysis. Research in Comparative and International Education, 1(3), 198-209.

[32] Teixeira, A. A. C., and Rocha, M. F. (2010), Cheating by economics and business undergraduate students: an exploratory international assessment, High Education, 59:663-701.

[33] Treviño, L.K., Butterfield, K. and McCabe, D. (1999), The ethical context in organizations: Influences on employee attitudes and behaviours, Business Ethics Quarterly, 8 (3):447-476.

[34] Wilkinson, J. Staff and Student Perceptions of Plagiarism and Cheating. (2009), International Journal of Teaching and Learning in Higher Education, 20(2), p 98 -105.

[35] Woessner, M. (2004), Beating the house: How inadequate penalties for cheating make plagiarism an excellent gamble, PS: Political Science and Politics, 37(2), 313-320. 